\title{
Mechanisms of Action of Probiotics in Intestinal Diseases
}

\author{
Ann M. O'Hara ${ }^{1}$ and Fergus Shanahan ${ }^{1,2, *}$ \\ ${ }^{1}$ Alimentary Pharmabiotic Centre and ${ }^{2}$ Department of Medicine, University College \\ Cork, National University of Ireland, Ireland

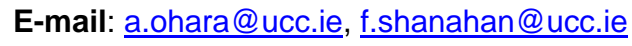

Received September 20, 2006; Revised December 21, 2006; Accepted December 21, 2006;

Published January 10, 2007

Intestinal microbiota is a positive health asset that exerts a conditioning effect on intestinal homeostasis. Resident bacteria deliver regulatory signals to the epithelium and instruct mucosal immune responses. Recent research has revealed a potential therapeutic role for the manipulation of the microbiota and exploitation of host-microbial signalling pathways in the maintenance of human health and treatment of various mucosal disorders. A variety of pharmabiotic strategies, such as the use of specific members of the microbiota, their surface components, or metabolites, as well as genetically modified commensal bacteria, are being investigated for their ability to enhance the beneficial components of the microbiota. It is clear that engagement with host cells is central to pharmabiotic action, and several strain-specific mechanisms of action have been elucidated. However, the molecular details underpinning these mechanisms remain almost entirely unknown. Understanding how pharmabiotics exert their beneficial effects is critical for the establishment of definitive selection criteria for certain pharmabiotic strategies for specific clinical conditions. Scientifically accredited evidence of efficacy and studies to elucidate the molecular mechanisms of host-microbiota interactions are needed to lend credence to the use of pharmabiotic strategies in clinical medicine.

KEYWORDS: commensal bacteria, enteric infection, inflammation, inflammatory bowel disease, intestinal epithelium, microbiota, pharmabiotic, probiotic

\section{INTRODUCTION}

The human gastrointestinal tract harbours a diverse bacterial community that comprises more than 1000 different species, and outnumbers human somatic and germ cells tenfold[1]. Historically, microbial research focused on the mechanisms by which enteric pathogens mediate tissue damage and disease. More recently, a circumstantial role of intestinal bacteria in the pathogenesis of various intestinal disorders has been recognised. For example, in genetically susceptible individuals, some components of commensal organisms can trigger aberrant immune responses that contribute to the pathogenesis of inflammatory bowel disease[2]. Innate immune responses to indigenous bacteria prime the immune system and influence adaptive responses to exogenous antigens. It follows that genes that were once survival factors in an earlier 
era, could now become risk factors for immune hypersensitivity disorders in the modern sanitised environments of developed nations[3]. Gut bacteria have been implicated in obesity and, under certain circumstances, they can fuel the progression towards colorectal malignancy[4,5]. Despite these adverse associations, intestinal microbiota fundamentally impact human health also.

Under normal circumstances, commensal bacteria are an essential health asset that exert a conditioning and protective influence on intestinal structure and homeostasis. Intestinal bacteria protect against infection, and actively exchange developmental and regulatory signals with the host that prime and instruct mucosal immunity[1]. Colonisation of germ-free mice with a single species, Bacteroides thetaiotaomicron, has been shown to affect the expression of a variety of host genes. These include genes associated with nutrient uptake, metabolism, angiogenesis, mucosal barrier function, and the development of the enteric nervous system[6]. Interactions between gut-associated lymphoid tissues and colonising bacteria early in life are crucial for appropriate development of functioning mucosal and systemic immunoregulatory systems[7,8]. Thus, individual variations in immunity may be influenced by the composition of the colonising microbiota. Bacterial metabolism confers many benefits to gut physiology, and commensal bacteria represent a rich repository of metabolites that can be mined for therapeutic benefit[1]. Intestinal bacteria are not uniform in their ability to drive mucosal inflammatory responses. Some commensal species such as $B$. vulgatus are proinflammatory[9]. Conversely, other species lack inflammatory capacity, and certain bacteria including strains of bifidobacteria and lactobacilli can even attenuate inflammatory responses[10,11,12].

\section{PROBIOTICS AS A THERAPEUTIC STRATEGY}

At the turn of the last century, the use of "friendly" microbes present in fermented foods for the purpose of health maintenance and disease prevention was first proposed by Metchnikoff[13]. These beliefs have been substantiated by recent research, which indicates that enhancing the beneficial components of the gut microbiota using probiotics represents a realistic therapeutic strategy in the maintenance of human health and in the treatment of various intestinal disorders. A probiotic is usually defined as a live microorganism that, when consumed in adequate quantities, confers a health benefit on the host. However, as our understanding of host-microbial interactions progresses, this definition is continually revised. It is less restrictive to define probiotics as commensal microorganisms that can be harnessed for health benefits.

Criteria for designating a commensal strain as a probiotic include human origin; acid and bile resistance; survival of gastrointestinal transit; nonpathogenic, production of antimicrobial substances; and immune modulatory activity[14]. The most commonly used probiotics include species of lactic acid bacteria (e.g., lactobacilli and bifidobacteria) that lack inflammatory activity. However, other bacteria including nonpathogenic Escherichia coli; yeasts, particularly Saccharomyces boulardii; and multistrain cocktails, such as VSL\#3, have been used as probiotics also. VSL\#3 comprises Lactobacillus casei, L. plantarum, $L$. acidophilus, L. delbrueckii subspecies bulgaricus, Bifidobacterium infantis, B. breve, B. longum, and Streptococcus salivarius subspecies thermophilus. Fermented dairy products enriched with probiotic bacteria are a remarkably successful category of functional foods. It is estimated that annual sales of dailydose probiotic drinks exceed 1.2 billion euro in Europe alone[15].

By definition, probiotics have a high safety profile and the tolerance is usually excellent. Although many of the commercial probiotic products have been officially designated as "generally regarded as safe", some reports of infections probably caused by probiotics have been published[16,17]. However, this is rare, and these isolated incidences have occurred in immunocompromised patients or those with severe underlying disease. Obviously, the administration of probiotics to such patients groups should be approached with caution. Several studies have administered probiotic preparations to children; they are well tolerated and safe[18,19,20]. 


\section{THE EVIDENCE FOR PROBIOTIC EFFICACY}

Probiotic bacteria have demonstrated health-promoting effects in intervention studies in several clinical conditions. The best evidence for probiotics in any condition is in the treatment and prevention of enteric infections and postantibiotic syndromes. Several meta-analyses studies have established probiotic efficacy in acute infectious diarrhoea and the prevention of antibiotic-associated diarrhoea[21,22,23,24]. Certain probiotics may reduce the recurrence of Clostridium difficile-associated diarrhoea also[25,26]. Recently, the Cochrane collaboration conducted a comprehensive systematic review of the evidence for the use of probiotics in infectious diarrhoea in both adults and children. The review concluded that probiotics were a useful adjuvant to rehydration therapy in the treatment of acute infectious diarrhoea[27].

Necrotising enterocolitis is a severe gastrointestinal inflammatory disease that is a common cause of morbidity among premature, low-birth-weight infants. Factors contributing to its pathogenesis include naïve intestinal and immune function, enteral feeding, and gas-producing bacteria. In a number of studies, probiotics have been shown to reduce the incidence and severity of necrotising enterocolitis by contributing to the establishment of a natural, rather than an abnormal, microbiota[28,29]. In affected neonates, probiotics appear to be safe and more effective than other strategies. The administration of probiotics to mothers prior to delivery and to breastfed infants has been shown to influence gut immunity in the newborn positively[30].

Irritable bowel syndrome is a common functional bowel disorder and a role of probiotics in its treatment is promising. The administration of B. infantis 35624, but not lactobacilli, has been shown to improve the symptom profile of patients with irritable bowel syndrome[31,32]. In patients with pouchitis, a nonspecific inflammation of the ileal reservoir, probiotic bacteria have demonstrated efficacy in maintaining remission in chronic pouchitis or preventing the development of pouchitis in the first place[33,34,35]. Nevertheless, the wider open clinical experience with probiotics in pouchitis patients is inconsistent and may be related to variability in patient populations or the choice of probiotic preparation. Ulcerative colitis and Crohn's disease, collectively known as inflammatory bowel disease, are chronic relapsing and remitting inflammatory disorders of the gastrointestinal tract. In ulcerative colitis, E. coli Nissle 1917, L. rhamnosus GG, and VSL\#3 have shown efficacy similar to the drug mesalazine in maintaining remission[36,37,38]. Probiotics have induced remission of acute ulcerative colitis also[38,39]. However, in a randomised, double-blind, placebo-controlled trial, B. infantis 35624 and L. salivarius subspecies salivarius UCC118, probiotics that have attenuated disease severity in animal models of colitis, did not demonstrate efficacy in the maintenance of steroid-induced remission of ulcerative colitis[40]. The differences in efficacy between animal and human inflammatory bowel disease may reflect the timing of administration, differences in disease severity, or effective probiotic dose/body weight. Saccharomyces boulardii and E. coli Nissle 1917 have been effective in the maintenance of remission in patients with Crohn's disease[41,42]. However, controlled studies of probiotics in Crohn's disease did not find efficacy for L. rhamnosus GG or L. johnsonii LA1 as maintenance therapies for Crohn's disease[43,44]. Larger, well-powered, randomised control trials are needed to determine conclusively whether there is a role for certain strains of probiotics or probiotic combinations in Crohn's disease.

There is evidence to suggest that the gastric colonisation and activity of Helicobacter pylori can be inhibited by probiotics. Probiotics do not eliminate the pathogen, but suppress its growth and reduce gastric inflammation[45,46]. In patients with severe acute pancreatitis, L. plantarum $299 \mathrm{v}$ was protective against pancreatic sepsis[47]. The consumption of probiotics has been linked to the improvement of high cholesterol and lactose intolerance, and the potential therapeutic use of probiotics in the prevention and treatment of human malignancy, atopic/allergic diseases, and rheumatoid arthritis are additional areas of potential application[48,49,50]. 


\section{MECHANISMS OF PROBIOTIC ACTION}

Experimental models have revealed that probiotics differ greatly in their mechanism of action; any singular mechanism is unlikely to account for all of their clinical effects. Significant differences exist, not only between probiotic species, but also between certain strains. In addition to specific interactions between probiotic bacteria and host immune cells, microbe-microbe interactions confound the complexity of the signalling network in vivo. Such complex interactions probably account for the versatility of probiotic action and could explain some of the varying results observed within the different clinical trials. Understanding the various mechanisms of probiotic action is crucial for the establishment of definitive selection criteria for certain strains or combination of strains for specific clinical conditions. Although the molecular details of probiotic mechanisms remain unresolved, numerous studies have indicated that the beneficial effects of probiotics may be either direct or indirect through modification of the local microbiota, epithelial barrier function, intestinal inflammation, or the immune system (Fig. 1).

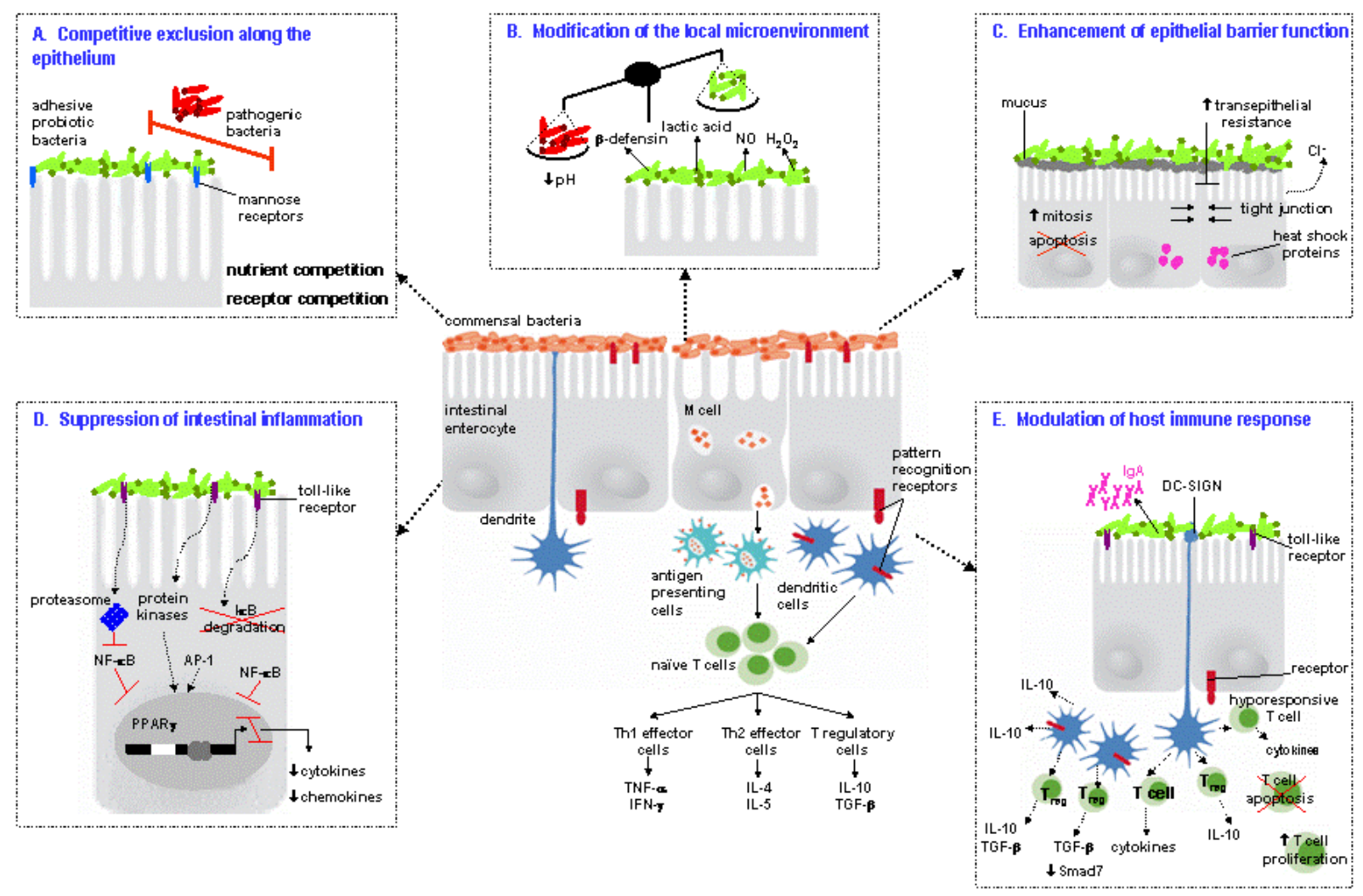

FIGURE 1. Mechanisms of action of probiotics in intestinal diseases. In the intestine, immunosensory cells are continually sampling and responding to the microbiota. Pattern recognition receptors expressed by immunocytes mediate the detection of bacterial antigens. Surface enterocytes sense danger signals and secrete immune mediators in response to antigens. Specialised epithelial cells, termed $\mathrm{M}$ cells, transport and deliver antigens to antigen-presenting cells, which in turn process antigens and present them to naïve T cells. Dendritic cells also survey and sample the mucosal microenvironment. Dendritic cells act as switches for immune responsiveness and determine the nature of the response by promoting either Th1 or Th2 effector cells or regulatory T cells and their associated cytokines. The figure illustrates several mechanisms of probiotic action that are relevant to intestinal diseases: A, competitive exclusion along the epithelium; B, modification of the local microenvironment; C, enhancement of epithelial barrier function; D, suppression of intestinal inflammation; E, modification of the host immune reponse. These mechanisms are strainspecific and are not mutually exclusive. AP-1, activator protein-1; $\mathrm{Cl}^{-}$, chloride; DC-SIGN, dendritic cell-specific intercellular adhesion molecule 3-

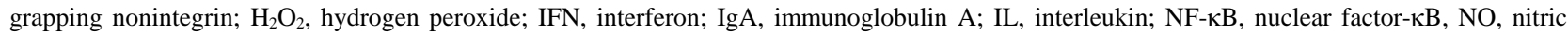
oxide; PPAR, peroxisome proliferator-activated receptor; TGF, transforming growth factor; TNF, tumour necrosis factor- $\alpha$; Treg, regulatory T cell. 


\section{Competitive Exclusion Along the Epithelium}

The intestinal epithelium is an important barrier that restricts the penetration of luminal antigens and microbes. Interaction between bacterial antigens and host cell receptors is a crucial step in the pathogenesis of many intestinal diseases. Preventing such interactions thus represents a potential therapeutic strategy. Several probiotic bacteria including bifidobacteria and lactobacilli adhere to mucosal tissue in a strainspecific manner[51,52,53,54,55]. This limits nutrient availability to other bacteria, enhances the intestinal persistence of the probiotic bacteria, and limits pathogen access to the epithelium (Fig. 1A).

Genomics-based homology searches have led to the identification of several adhesion factors in probiotic bacteria[56,57]. Surface structures, such as elongation factor Tu and GroEL of L. johnsonii LA1, and adhesins from other lactobacilli can bind epithelial cell mucins and mannose[58,59,60,61]. Enteropathogenic E. coli are known to bind to epithelial cells via mannose receptors. Therefore, it is feasible that probiotic strains with similar adherence capabilities could inhibit pathogen attachment at these or other binding sites, or impede the penetration of invasive pathogens across the mucosal layer. Moreover, GroEL has been shown to mediate the aggregation of $H$. pylori[59]. Probiotics, such as L. bulgaricus, which adhere weakly to the intestinal mucosa, are less effective than adhesive strains against enteric pathogens. Adhesive probiotic bacteria, such as L. plantarum 299v, L. acidophilus ATCC4356, and Streptococcus thermophilus ATCC19258 have been shown to prevent pathogen-induced electrolyte secretion and barrier dysfunction. However, these protective effects were only observed when the probiotics were added prior to pathogen challenge[54,62]. There is evidence to indicate that particular combinations of probiotic strains may have synergistic adhesive effects, thereby increasing the efficacy of a probiotic preparation[63].

In rotavirus infection, $L$. casei $\mathrm{DN}-114001$ has been shown to use soluble probiotic-derived factors to modify the glycosylation state of epithelial cell receptors[64]. This inhibits the adhesion of the virus. In contrast, bacterial species that do not induce glycosylation changes are not protective against the virus. Pathogenic organisms induce diarrhoea by diverse processes; therefore, multiple other mechanisms probably contribute to probiotic-mediated improvement of diarrhoea.

\section{Modification of the Local Microenvironment}

Studies using in vivo expression screening technology have identified a variety of probiotic genes that are induced in the murine gastrointestinal tract[65,66]. Such studies indicate that probiotic bacteria are responsive to gut conditions and metabolically active in vivo. Administration of probiotic bacteria can modify the composition of the local microenvironment in two key ways. First, probiotic bacteria mediate antimicrobial effects that can directly inhibit pathogenic bacteria; second, they enhance the richness and diversity of the more beneficial components of the gut microbiota (Fig. 1B). Probiotics have been shown to suppress pathogen growth through the release of a variety of antimicrobial factors. These include defensins, bacteriocins, hydrogen peroxide, nitric oxide, and short chain fatty acids, such as lactic and acetic acids, which reduce the $\mathrm{pH}$ of the lumen[67].

The effects of the administration of probiotic bacteria on the indigenous mucosa-related microenvironment are poorly understood. Nevertheless, a number of recent studies demonstrate that probiotics play a role in the restoration or maintenance of a protective intestinal microbiota. In patients with pouchitis, VSL\#3 therapy increased the diversity of the bacterial community, especially the anaerobic members, whereas the diversity of the fungal flora was repressed[68]. In contrast, patients who relapsed in the placebo group showed reduced microbial diversity. In a randomised, double-blind, placebo-controlled trial, the administration of $L$. johnsonii LA1 to healthy volunteers was found to increase total numbers of bifidobacteria and lactobacilli, as well as faecal lactic acid concentrations. This was coupled with decreased faecal $\mathrm{pH}$ and reduced numbers of clostridia[69]. By inhibiting the adverse components and promoting the beneficial components, probiotic bacteria favourably modify the local microbiota. 


\section{Enhancement of Epithelial Barrier Function}

Alterations in epithelial transport and barrier functions are a common consequence of a variety of intestinal disorders including enteric infections. Defects in epithelial barrier function may also precede the onset of inflammation in patients with inflammatory bowel disease[70]. In contrast, commensal bacteria help to fortify the epithelial barrier by various mechanisms. For example, colonisation of germ-free mice with the commensal bacteria, Bacteroides thetaiotaomicron, induces the expression of the complement-inhibitor, decay-accelerating factor and complement-reactive protein-ductin, a putative receptor for cytoprotective intestinal trefoil factors[71]. Exposure of colonic epithelial cell lines to bacterial ligands also results in apical tightening and sealing of tight junctions and increased transepithelial resistance[72].

Several probiotic bacteria have been shown to preserve epithelial barrier function and prevent and repair mucosal damage triggered by food antigens, drugs (such as aspirin), enteric pathogens, and proinflammatory cytokines[54,73,74,75]. These protective effects are mediated by a number of mechanisms (Table 1). These include the induction of mucin secretion, the maintenance or enhancement of cytoskeletal and tight junction protein phosphorylation, the restoration of chloride secretion, and the augmentation of transepithelial resistance (Fig. 1C). VSL\#3 has been shown to up-regulate heat shock proteins known for their ability to maintain cytoskeletal integrity and protect intestinal enterocytes from injury against oxidative stress[76]. Mitogen-activated protein kinases have been implicated in the induction of heat shock proteins by soluble factors from L. rhamnosus GG[77]. Lactobacillus rhamnosus GG can also exert mitogenic effects by increasing cell proliferation in the villi of germ-free rats, thereby enhancing mucosal regeneration[78]. Moreover, probiotic bacteria can promote cell survival by preventing apoptosis in intestinal epithelial cells through the regulation of both anti- and proapoptotic signal transduction pathways[79]. Together, these varying effects on the epithelium may be instrumental in improving mucosal barrier function and integrity. It is noteworthy that in a study of cytokine-induced barrier dysfunction, a commensal strain, $B$. thetaiotaomicron, was unable to reproduce all of the protective effects mediated by $L$. acidophilus ATCC4356 and S. thermophilus ATCC19258. This emphasises that bacteria selected for their probiotic properties may have special abilities that are not necessarily shared by other commensal bacteria[74].

\section{Suppression of Intestinal Inflammation}

Intestinal epithelial cells sense danger signals within the luminal microenvironment. The transcription factor, nuclear factor (NF)- $\kappa \mathrm{B}$, is a master coordinator of immune and inflammatory responses to pathogenic bacteria and other stress signals. However, most commensal bacteria do not activate NF-кB. Instead, some commensal bacteria antagonise NF- $\kappa B$ within enterocytes by a variety of mechanisms. These include degradation of the NF- $\kappa$ B inhibitor I $\kappa \mathrm{B}-\alpha$, or by the nuclear export of the p65 subunit of NF- $\kappa \mathrm{B}$ in a peroxisome proliferator-activated receptor (PPAR) $\gamma$-dependent manner[80,81]. The anti-inflammatory effects of a number of probiotic bacteria including Bifidobacterium infantis 35624 and L. salivarius

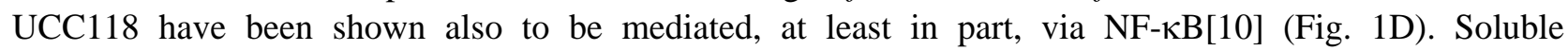
components from VSL\#3 can inhibit IкB degradation by inhibiting epithelial proteasome function[76]. Lactobacillus reuteri has been shown to inhibit the nuclear translocation of NF- $\mathrm{BB}$ by preventing the degradation of IкB[11]. This was accompanied by an increased expression of nerve growth factor, which has anti-inflammatory properties. This finding implicates a role of the enteric nervous system in hostmicrobial interactions. 
TABLE 1

Probiotic-Mediated Enhancement of Barrier Function in Experimental Models

\begin{tabular}{|c|c|c|c|}
\hline Probiotic & Biologic Effect & Experimental Model & Ref. \\
\hline E. coli Nissle 1917 & Increased transepithelial resistance & T84, HT-29 & [12] \\
\hline L. acidophilus & $\begin{array}{l}\text { Maintenance of tight junctions and increased } \\
\text { occludin expression }\end{array}$ & Rats & [129] \\
\hline \multirow[t]{2}{*}{$\begin{array}{l}\text { L. acidophilus } \\
\text { ATCC4356 }\end{array}$} & $\begin{array}{l}\text { Enhanced phosphorylation of actinin and occludin in } \\
\text { epithelial cells }\end{array}$ & HT-29/cl.19A, Caco-2 & [54] \\
\hline & $\begin{array}{l}\text { Restoration of chloride secretion and enhanced } \\
\text { epithelial resistance }\end{array}$ & HT-29/cl.19A, Caco-2 & [74] \\
\hline \multirow[t]{2}{*}{ L. acidophilus LB } & $\begin{array}{l}\text { Maintenance of } \mathrm{F} \text { actin and transport and enzymatic } \\
\text { activity }\end{array}$ & Caco-2/TC7 cells & [130] \\
\hline & $\begin{array}{l}\text { Prevented impaired intestinal permeability and } \\
\text { protected tight junction proteins }\end{array}$ & HT-29 & [73] \\
\hline L. acidophilus R0011 & Improved intestinal barrier function & Rats & [131] \\
\hline L. brevis & Reduced colonic permeability & Rat & [132] \\
\hline L. casei & Enhanced epithelial cell glycosylation & HT-29/MTX cells & [64] \\
\hline L. casei GG & Up-regulation of MUC2 expression & Caco-2 & [133] \\
\hline L. helveticus R0052 & Improved intestinal barrier function & Rats & [131] \\
\hline L. plantarum 299v & $\begin{array}{l}\text { Up-regulation of MUC2 and MUC3 mRNA and } \\
\text { enhanced mucin secretion }\end{array}$ & HT-29 & {$[52,134]$} \\
\hline \multirow[t]{4}{*}{ L. rhamnosus GG } & $\begin{array}{l}\text { Up-regulation of MUC2 and MUC3 mRNA and } \\
\text { enhanced mucin secretion }\end{array}$ & HT-29 & {$[52,134]$} \\
\hline & Promoted cell proliferation in the villi & Germ-free rats & [78] \\
\hline & $\begin{array}{l}\text { Prevented apoptosis by activating signal } \\
\text { transduction pathways in intestinal epithelial cells }\end{array}$ & YAMC cells, HT-29 & [79] \\
\hline & $\begin{array}{l}\text { Induction of cytoprotective heat shock proteins by } \\
\text { activating signal transduction pathways in intestinal } \\
\text { epithelial cells }\end{array}$ & YAMC cells & [77] \\
\hline \multirow[t]{2}{*}{$\begin{array}{l}\text { S. thermophilus } \\
\text { ATCC19258 }\end{array}$} & $\begin{array}{l}\text { Enhanced phosphorylation of actinin and occludin in } \\
\text { epithelial cells }\end{array}$ & HT-29/cl.19A, Caco-2 & [54] \\
\hline & $\begin{array}{l}\text { Restoration of chloride secretion and enhanced } \\
\text { epithelial resistance }\end{array}$ & HT-29/cl.19A, Caco-2 & [74] \\
\hline \multirow[t]{3}{*}{ VSL\#3 } & Enhanced epithelial resistance & IL-10 deficient mice; T84 & [97] \\
\hline & $\begin{array}{l}\text { Increased transepithelial resistance and increased } \\
\text { mucin expression }\end{array}$ & T84, HT-29 & [12] \\
\hline & Induction of cytoprotective heat shock proteins & YAMC cells & [76] \\
\hline
\end{tabular}

NF- $\kappa B$ transcriptionally regulates interleukin (IL)-8, a potent neutrophil-recruiting and activating chemokine. IL-8 is secreted by intestinal enterocytes in response to several pathogenic bacteria[82]. A variety of probiotic bacteria including VSL\#3, L. reuteri, L. salivarius UCC118, and B. infantis 35624 have been shown to suppress IL-8 secretion from infected intestinal epithelial cells[10,11,12]. Moreover, probiotic treatment limits inflammatory cytokine secretion from inflamed mucosal explants from inflammatory bowel disease patients[83,84]. Although the NF- $\kappa B$ pathway has been most frequently implicated, other intracellular signal transduction pathways have also been associated with the protective effects mediated by various probiotic bacteria. These include mitogen-activated protein kinase, protein kinase B, activator protein-1, and PPAR- $\gamma$ pathways[12,79,85,86]. Many of the mechanisms are strain specific and other signal transduction pathways are likely to account for the anti-inflammatory effects of other probiotic bacteria. 


\section{Modulation of Host Immune Response}

Commensal bacteria can modulate the immune system at both a systemic and local level. Signals mediated by commensal bacteria or their ligands are essential for optimal mucosal and immune development, and to maintain and repair the gut[87,88]. In the intestine, immunosensory cells, such as enterocytes, $\mathrm{M}$ cells, and dendritic cells, are continually sampling and responding to intestinal bacteria[1]. These immunocytes express pattern recognition receptors including toll-like receptors (TLRs) that engage bacterial signals, such as lipopolysaccharide, lipotechoic acid, bacterial DNA, and flagellin. This contributes to the activation of transcription factors and proinflammatory cascades in immunosensory cells. TLRs play a central role in the interpretation of the microenvironment and the discrimination of pathogen from commensal. Oral consumption of probiotics is associated with immune engagement and demonstrable systemic immunologic changes[89]. It appears that probiotics serve to mimic the commensal microbiota and exploit host-microbial signalling pathways (Fig. 1E). Of note, immune stimulation by probiotic bacteria in the gut can enhance immune protection at distal mucosal sites such as the urogenital and respiratory tracts[90].

Dendritic cells (DCs) sample bacteria and prime adaptive immunity by shaping T-cell responses and regulating the balance of $\mathrm{T}$ helper (Th) cell and regulatory $\mathrm{T}$-cell responses in the intestinal mucosa. Different strains of lactobacilli and other probiotic bacteria can modulate DC function by differentially inducing their maturation and the expression of cytokines, such as the regulatory cytokine IL-10[91,92]. It is interesting to note that DCs from different lymphoid compartments exhibit divergent cytokine responses to probiotic and pathogenic bacteria[93]. DC-lactobacilli interactions appear to be mediated, at least in part, by the binding of lactobacilli to a pattern recognition receptor termed DC-SIGN (DC-specific intercellular adhesion molecule 3-grabbing nonintegrin)[94]. On the other hand, lactobacilli that did not interact with DC-SIGN failed to induce IL-10-producing regulatory T cells. In animal models of disease, the therapeutic effects of probiotics are associated with a reduction in inflammatory cytokines, such as tumour necrosis factor- $\alpha$ and interferon- $\gamma$, and an induction of regulatory cytokines, particularly transforming growth factor (TGF)- $\beta[89,95,96,97]$. In certain clinical conditions, the protective effects of some probiotic bacteria, such as B. infantis 35624, have been associated with a normalisation of cytokine imbalances[31].

Some strains of probiotic bacteria, such as $L$. casei or L reuteri, but not L. plantarum, can promote tolerance-inducing DCs by priming DCs to drive the development of regulatory $\mathrm{T}$ cells[94,98]. These regulatory T cells produce high levels of IL-10 and suppress the proliferation of effector T cells in an IL10-dependent manner. Similarly, VSL\#3 can ameliorate Th1 cell-mediated murine colitis by restoring cytokine balance through the induction of IL-10- and TGF- $\beta$-bearing regulatory T cells[99]. Increased TGF- $\beta$ signalling induced by $B$. breve in preterm infants has been associated with reduced expression of Smad7, a negative regulator of TGF- $\beta[100]$. Interactions between DCs and L. rhamnosus GG can induce hyporesponsive $\mathrm{T}$ helper cells[101]. Furthermore, probiotic bacteria may facilitate the polarisation of the naïve immune system by skewing it from Th2 to Th1 responses, thereby promoting humoral and cellmediated immunity[102]. The promotion of Th1 immune responses by probiotic bacteria may account for their reported suppression of symptoms of atopic diseases, which are typically driven by skewed Th2 responses[98]. Probiotics that suppress that production of anti-inflammatory cytokines and/or enhance the production of IL-10 and TGF- $\beta$ confer protection against atopic diseases in infants[103].

Proliferation of $\mathrm{T}$ cells in response to antigen stimulation is required to expand the T-cell pool and generate functional effector cells. It has been proposed that E. coli Nissle 1917 limits intestinal inflammation by attenuating the expansion of newly recruited $\mathrm{T}$ cells into the mucosa[104]. Probiotic bacteria also impact on T-cell apoptosis in a species-specific manner. Escherichia coli Nissle 1917 does not induce T-cell apoptosis, whereas the apoptotic abilities of L. brevis CD2 have been associated with probiotic arginine deiminase and/or sphingomyelinase activity[104,105].

Increased levels of secretory immunoglobulin (Ig)-A and numbers of phagocytic Kupffer cells were recorded in germ-free mice monoassociated with the probiotic Saccharomyces boulardii compared with germ-free controls[106]. This comparative study suggested that in addition to enhancing cell-mediated immune responses, probiotic bacteria could also augment innate and humoral immune responses. In 
agreement with other studies, a recent randomised, double-blind, placebo-controlled trial demonstrated that the administration of two probiotic bacteria, L. gasseri CECT5714 and L. coryniformis, increased the proportion and activity of phagocytic and natural killer cells as well as levels of IgA in healthy adults[107,108,109]. The administration of probiotic bacteria in infectious challenges leads to an increase in the levels of pathogen-specific IgA [90], and IgA responses are enhanced in formula-fed infants supplemented with probiotics compared with infants receiving placebo[110]. Of note, the induction of IgA in the gut is heavily dependent on TGF- $\beta$, which is also closely involved in the maturation of regulatory $\mathrm{T}$ cells[111]. It has been postulated that probiotic strains that are capable of increasing antibody production in the gut may have potential as adjunct therapies to boost immune responsiveness to oral vaccination[112].

\section{THE CASE FOR PHARMABIOTIC ACTION}

Direct interactions with viable bacteria are required for the protective effects mediated by certain strains of probiotic bacteria[11,54]. Nonetheless, whether or not the beneficial actions of all probiotic strains are dependent on live microorganisms or whether oral administration is required for clinical efficacy is uncertain. The answers to these questions are probably multifactorial and strain specific.

In mice, the subcutaneous administration of $L$. salivarius UCC118 was shown to attenuate colitis and proinflammatory cytokine production and protect against collagen arthritis[48]. This raises the possibility that probiotic bacteria might not have to be taken orally to have therapeutic benefit. Moreover, nonviable irradiated probiotic bacteria and the subcutaneous administration of DNA derived from VSL\#3 have demonstrated protective effects in a number of animal models of colitis[113]. These effects were shown to be mediated not by bacterial metabolites or ability to colonise the colon, but by probiotic DNA binding to TLR9. Bacterial DNA contains immunostimulatory sequences which engage the host TLR9 receptor. These sequences, as well as some of their synthetic oligonucleotides, have also demonstrated protective effects in murine models of colitis and in biopsies from patients with active ulcerative colitis[114,115]. Another study demonstrated that DNA from VSL\#3, but not E. coli, attenuated NF- $\kappa \mathrm{B}$ signalling and inhibited proinflammatory cytokine secretion in intestinal enterocytes[116].

Secreted bioactive molecules or surface proteins of probiotic bacteria may also modulate host immune responses. Irradiated or sonicated probiotic bacteria can affect the maturation and cytokine secretion profile of DCs[91,92]. Supernatant from cultures of B. breve C50 can activate DCs via a mechanism that involves the peptidoglycan receptor TLR2[117]. Metabolites derived from B. breve C50 and Streptococcus thermophilus 065 have demonstrated anti-inflammatory effects that are not lost by crossing the epithelial barrier[118]. The composition of cell surface structures, such as lipotechoic acid of L. plantarum NCIMB8826, have been shown to differentially impact on the immune system through a mechanism that involves TLR2[119]. A recent report demonstrated that administration of a high exopolysaccharideproducing lactobacillus (L. delbrueckii subspecies bulgaricus B3) attenuated experimental colitis significantly more than a low exopolysaccharide-producing strain (L. delbrueckii subspecies bulgaricus A13)[120]. Conjugated linoleic acid produced by some probiotic bacteria also has important antiinflammatory properties[121]. Collectively, these reports challenge the traditional assumption that live bacteria are required for therapeutic efficacy. As a result, the less-restrictive term "pharmabiotic" has been coined to encompass all forms of microbial manipulation in therapeutics[1]. Pharmabiotics comprise probiotics, as well as prebiotics and synbiotics, live and dead organisms, components and metabolites thereof, and genetically modified commensal bacteria.

\section{DESIGNER PROBIOTICS}

The genetic modification of bacteria for the site-specific delivery of therapeutic molecules represents a realistic pharmabiotic strategy. In mice, genetically engineered L. lactis has been used to deliver IL-10 or cytoprotective trefoil factors locally to the gut[122,123,124]. More recently, in the first human trial with 
genetically engineered therapeutic bacteria, ten Crohn's disease patients were treated with modified L. lactis in which the thymidylate synthase gene was replaced with a synthetic sequence encoding human IL-10. When the modified bacteria are deprived of thymine or thymidine, they are not viable. Neither thymine nor thymidine is readily available in the external environment, thereby limiting the viability of the excreted organism. The treatment was safe, disease activity was reduced, and the modified bacteria were biologically contained[125]. Therefore, bacterial-based topical delivery of biologically active proteins represents a highly promising and safe therapeutic strategy for combating mucosal diseases. The results of larger placebo-controlled trials with this modified L. lactis are eagerly awaited.

Recombinant "designer" probiotics that express molecular mimics of host toxin receptors on their surface are being investigated for their ability to bind bacterial toxins, thereby preventing enteric infections[126]. In a recent study, a chimeric lipopolysaccharide containing a glycosylated lipid that mimics the cholera toxin receptor was expressed into nonpathogenic E. coli CWG308[127]. The recombinant probiotic could bind cholera toxin, inhibit its cytotoxicity, and also protect infant mice from challenge with Vibro cholerae. Whether this or similar recombinant probiotic strategies are efficacious in enteric infections in humans has not yet been demonstrated. Nonetheless, the potential for these designer probiotics is limited only by one's imagination, but public health and other safety concerns must be resolved before routine clinical use in humans.

\section{CONCLUSIONS}

The increasing availability of commensal genomes should facilitate the identification of commensal effector molecules or other components with pharmabiotic potential[128]. The possibility of using these molecules to target distinct points of intracellular signalling cascades specifically might alleviate inflammation in a target area and overcome the global immunosuppressive effects associated with current therapies. By combining comparative genomic-based approaches with molecular models, it should become possible to select a particular probiotic or pharmabiotic strategy for a specific benefit. Overall, the rationale of pharmabiotic therapy appears to be justified. However, clinical evidence of efficacy requires validation, and unsubstantiated health claims need more stringent regulation. These issues can be resolved through larger, rigorously designed, placebo-controlled, double-blind clinical trials. The microbial, immunological, and functional characteristics of individual probiotic strains and their effects in different clinical conditions require clarification. Moreover, in order for consumers and clinicians to endorse pharmabiotic strategies unequivocally, it is crucial to identify the precise mechanisms by which probiotics and pharmabiotics influence human health. Host-microbial signalling is central to pharmabiotic action, and although the various modes of action described here are multifactorial and strain specific, it is important to consider that they are not mutually exclusive. Furthermore, the molecular details behind these mechanisms remain almost entirely unknown. Further studies of physiological interactions within the complex network of hostmicrobiota and microbial-microbial signalling in gut health and disease should lead to the optimal exploitation of pharmabiotic approaches for different clinical conditions.

\section{ACKNOWLEDGEMENTS}

The authors are supported in part by Science Foundation Ireland. Professor Shanahan has been affiliated with a university campus-based company (Alimentary Health Ltd). The content of this article was neither influenced nor constrained by this fact. 


\section{REFERENCES}

1. $\quad$ O'Hara, A.M. and Shanahan, F. (2006) The gut flora as a forgotten organ. EMBO Rep. 7, 688-693.

2. Shanahan, F. (2004) Host-flora interactions in inflammatory bowel disease. Inflamm. Bowel Dis. 10(Suppl 1), S1624.

3. Rook, G.A. and Brunet, L.R. (2005) Microbes, immunoregulation, and the gut. Gut 54, 317-320.

4. Hope, M.E., Hold, G.L., Kain, R., and El-Omar, E.M. (2005) Sporadic colorectal cancer--role of the commensal microbiota. FEMS Microbiol. Lett. 244, 1-7.

5. $\quad$ Backhed, F., Ding, H., Wang, T., Hooper, L.V., Koh, G.Y., Nagy, A., Semenkovich, C.F., and Gordon, J.I. (2004) The gut microbiota as an environmental factor that regulates fat storage. Proc. Natl. Acad. Sci. U. S. A. 101, 1571815723.

6. Hooper, L.V., Wong, M.H., Thelin, A., Hansson, L., Falk, P.G., and Gordon, J.I. (2001) Molecular analysis of commensal host-microbial relationships in the intestine. Science 291, 881-884.

7. Cebra, J.J. (1999) Influences of microbiota on intestinal immune system development. Am. J. Clin. Nutr. 69, 1046S1051S.

8. Shanahan, F. (2002) The host-microbe interface within the gut. Best Pract. Res. Clin. Gastroenterol. 16, 915-931.

9. Sartor, R.B. (1997) The influence of normal microbial flora on the development of chronic mucosal inflammation. Res. Immunol. 148, 567-576.

10. O'Hara, A.M., O'Regan, P., Fanning, A., O'Mahony, C., MacSharry, J., Lyons, A., Bienenstock, J., O'Mahony, L., and Shanahan, F. (2006) Functional modulation of human intestinal epithelial cell responses by Bifidobacterium infantis and Lactobacillus salivarius. Immunology 118, 202-215.

11. Ma, D., Forsythe, P., and Bienenstock, J. (2004) Live Lactobacillus reuteri is essential for the inhibitory effect on tumor necrosis factor alpha-induced interleukin-8 expression. Infect. Immun. 72, 5308-5314.

12. Otte, J.M. and Podolsky, D.K. (2004) Functional modulation of enterocytes by gram-positive and gram-negative microorganisms. Am. J. Physiol. Gastrointest. Liver Physiol. 286, G613-626.

13. Metchnikoff, E. (1907) The Prolongation of Life: Optimistic Studies. Mitchell, C., Ed. William Heinemann, London. pp. 161-183.

14. Dunne, C., O'Mahony, L., Murphy, L., Thornton, G., Morrissey, D., O'Halloran, S., Feeney, M., Flynn, S., Fitzgerald, G., Daly, C., Kiely, B., O'Sullivan, G.C., Shanahan, F., and Collins, J. K. (2001) In vitro selection criteria for probiotic bacteria of human origin: correlation with in vivo findings. Am. J. Clin. Nutr. 73, 386S-392S.

15. Buss, D. (2004) Danone's top functional brand has America in its sights. New Nutr. Bus. 9, 3-5.

16. Riquelme, A.J., Calvo, M.A., Guzman, A.M., Depix, M.S., Garcia, P., Perez, C., Arrese, M., and Labarca, J.A. (2003) Saccharomyces cerevisiae fungemia after Saccharomyces boulardii treatment in immunocompromised patients. $J$. Clin. Gastroenterol. 36, 41-43.

17. De Groote, M.A., Frank, D.N., Dowell, E., Glode, M.P., and Pace, N.R. (2005) Lactobacillus rhamnosus GG bacteremia associated with probiotic use in a child with short gut syndrome. Pediatr. Infect. Dis. J. 24, $278-280$.

18. Vanderhoof, J.A. and Young, R.J. (1998) Use of probiotics in childhood gastrointestinal disorders. J. Pediatr. Gastroenterol. Nutr. 27, 323-332.

19. Gupta, P., Andrew, H., Kirschner, B.S., and Guandalini, S. (2000) Is Lactobacillus GG helpful in children with Crohn's disease? Results of a preliminary, open-label study. J. Pediatr. Gastroenterol. Nutr. 31, 453-457.

20. Malin, M., Suomalainen, H., Saxelin, M., and Isolauri, E. (1996) Promotion of IgA immune response in patients with Crohn's disease by oral bacteriotherapy with Lactobacillus GG. Ann. Nutr. Metab. 40, 137-145.

21. D'Souza, A.L., Rajkumar, C., Cooke, J., and Bulpitt, C.J. (2002) Probiotics in prevention of antibiotic associated diarrhoea: meta-analysis. BMJ 324, 1361.

22. Van Niel, C.W., Feudtner, C., Garrison, M.M., and Christakis, D.A. (2002) Lactobacillus therapy for acute infectious diarrhea in children: a meta-analysis. Pediatrics 109, 678-684.

23. Huang, J.S., Bousvaros, A., Lee, J.W., Diaz, A., and Davidson, E.J. (2002) Efficacy of probiotic use in acute diarrhea in children: a meta-analysis. Dig. Dis. Sci. 47, 2625-2634. Cremonini, F., Di Caro, S., Nista, E.C., Bartolozzi, F., Capelli, G., Gasbarrini, G., and Gasbarrini, A. (2002) Metaanalysis: the effect of probiotic administration on antibiotic-associated diarrhoea. Aliment. Pharmacol. Ther. 16, 1461-1467.

Plummer, S., Weaver, M.A., Harris, J.C., Dee, P., and Hunter, J. (2004) Clostridium difficile pilot study: effects of probiotic supplementation on the incidence of C. difficile diarrhoea. Int. Microbiol. 7, 59-62.

26. Wullt, M., Hagslatt, M.L., and Odenholt, I. (2003) Lactobacillus plantarum 299v for the treatment of recurrent Clostridium difficile-associated diarrhoea: a double-blind, placebo-controlled trial. Scand. J. Infect. Dis. 35, 365-367. Cochrane Database Syst. Rev. CD003048.

Bell, E.F. (2005) Preventing necrotizing enterocolitis: what works and how safe? Pediatrics 115, 173-174.

Hammerman, C. and Kaplan, M. (2006) Probiotics and neonatal intestinal infection. Curr. Opin. Infect. Dis. 19, 277282.

Rinne, M., Kalliomaki, M., Arvilommi, H., Salminen, S., and Isolauri, E. (2005) Effect of probiotics and breastfeeding on the bifidobacterium and lactobacillus/enterococcus microbiota and humoral immune responses. $J$. 
Pediatr. 147, 186-191.

31. O'Mahony, L., McCarthy, J., Kelly, P., Hurley, G., Luo, F., Chen, K., O'Sullivan, G.C., Kiely, B., Collins, J.K., Shanahan, F., and Quigley, E.M. (2005) Lactobacillus and bifidobacterium in irritable bowel syndrome: symptom responses and relationship to cytokine profiles. Gastroenterology 128, 541-551.

32. Whorwell, P.J., Altringer, L., Morel, J., Bond, Y., Charbonneau, D., O'Mahony, L., Kiely, B., Shanahan, F., and Quigley, E.M. (2006) Efficacy of an encapsulated probiotic Bifidobacterium infantis 35624 in women with irritable bowel syndrome. Am. J. Gastroenterol. 101, 1581-1590.

33. Gionchetti, P., Rizzello, F., Helwig, U., Venturi, A., Lammers, K.M., Brigidi, P., Vitali, B., Poggioli, G., Miglioli, M., and Campieri, M. (2003) Prophylaxis of pouchitis onset with probiotic therapy: a double-blind, placebo-controlled trial. Gastroenterology 124, 1202-1209.

34. Mimura, T., Rizzello, F., Helwig, U., Poggioli, G., Schreiber, S., Talbot, I.C., Nicholls, R.J., Gionchetti, P., Campieri, M., and Kamm, M.A. (2004) Once daily high dose probiotic therapy (VSL\#3) for maintaining remission in recurrent or refractory pouchitis. Gut 53, 108-114.

35. Gionchetti, P., Rizzello, F., Venturi, A., Brigidi, P., Matteuzzi, D., Bazzocchi, G., Poggioli, G., Miglioli, M., and Campieri, M. (2000) Oral bacteriotherapy as maintenance treatment in patients with chronic pouchitis: a double-blind, placebo-controlled trial. Gastroenterology 119, 305-309.

36. $\quad$ Kruis, W., Fric, P., Pokrotnieks, J., Lukas, M., Fixa, B., Kascak, M., Kamm, M.A., Weismueller, J., Beglinger, C., Stolte, M., Wolff, C., and Schulze, J. (2004) Maintaining remission of ulcerative colitis with the probiotic Escherichia coli Nissle 1917 is as effective as with standard mesalazine. Gut 53, 1617-1623.

37. Zocco, M.A., dal Verme, L.Z., Cremonini, F., Piscaglia, A.C., Nista, E.C., Candelli, M., Novi, M., Rigante, D., Cazzato, I.A., Ojetti, V., Armuzzi, A., Gasbarrini, G., and Gasbarrini, A. (2006) Efficacy of Lactobacillus GG in maintaining remission of ulcerative colitis. Aliment. Pharmacol. Ther. 23, 1567-1574.

38. Bibiloni, R., Fedorak, R.N., Tannock, G.W., Madsen, K.L., Gionchetti, P., Campieri, M., De Simone, C., and Sartor, R.B. (2005) VSL\#3 probiotic-mixture induces remission in patients with active ulcerative colitis. Am. J. Gastroenterol. 100, 1539-1546.

39. Rembacken, B.J., Snelling, A.M., Hawkey, P.M., Chalmers, D.M., and Axon, A.T. (1999) Non-pathogenic Escherichia coli versus mesalazine for the treatment of ulcerative colitis: a randomised trial. Lancet 354, 635-639.

40. Shanahan, F., Guarner, F., Von Wright, A., Vilpponen-Salmela, T., O'Donoghue, D., Kiely, B., and Progid Investigators (2006) A one year, randomised, double-blind, placebo controlled trial of a lactobacillus or a bifidobacterium probiotic for maintenance of steroid-induced remission of ulcerative colitis. Gastroenterology $\mathbf{1 3 0}$, A-44.

41. Guslandi, M., Mezzi, G., Sorghi, M., and Testoni, P.A. (2000) Saccharomyces boulardii in maintenance treatment of Crohn's disease. Dig. Dis. Sci. 45, 1462-1464.

42. Malchow, H.A. (1997) Crohn's disease and Escherichia coli. A new approach in therapy to maintain remission of colonic Crohn's disease? J. Clin. Gastroenterol. 25, 653-658.

43. Bousvaros, A., Guandalini, S., Baldassano, R.N., Botelho, C., Evans, J., Ferry, G.D., Goldin, B., Hartigan, L., Kugathasan, S., Levy, J., Murray, K.F., Oliva-Hemker, M., Rosh, J.R., Tolia, V., Zholudev, A., Vanderhoof, J.A., and Hibberd, P.L. (2005) A randomized, double-blind trial of Lactobacillus GG versus placebo in addition to standard maintenance therapy for children with Crohn's disease. Inflamm. Bowel Dis. 11, 833-839.

44. Marteau, P., Lemann, M., Seksik, P., Laharie, D., Colombel, J.F., Bouhnik, Y., Cadiot, G., Soule, J.C., Bourreille, A., Metman, E., Lerebours, E., Carbonnel, F., Dupas, J.L., Veyrac, M., Coffin, B., Moreau, J., Abitbol, V., BlumSperisen, S., and Mary, J.Y. (2006) Ineffectiveness of Lactobacillus johnsonii LA1 for prophylaxis of postoperative recurrence in Crohn's disease: a randomised, double blind, placebo controlled GETAID trial. Gut 55, 842-847.

45. Linsalata, M., Russo, F., Berloco, P., Caruso, M.L., Matteo, G.D., Cifone, M.G., Simone, C.D., Ierardi, E., and Di Leo, A. (2004) The influence of Lactobacillus brevis on ornithine decarboxylase activity and polyamine profiles in Helicobacter pylori-infected gastric mucosa. Helicobacter 9, 165-172.

46. Chatterjee, A., Yasmin, T., Bagchi, D., and Stohs, S.J. (2003) The bactericidal effects of Lactobacillus acidophilus, garcinol and Protykin compared to clarithromycin, on Helicobacter pylori. Mol. Cell Biochem. 243, $29-35$.

47. Olah, A., Belagyi, T., Issekutz, A., Gamal, M.E., and Bengmark, S. (2002) Randomized clinical trial of specific lactobacillus and fibre supplement to early enteral nutrition in patients with acute pancreatitis. Br. J. Surg. 89, 11031107.

48.

Sheil, B., McCarthy, J., O'Mahony, L., Bennett, M.W., Ryan, P., Fitzgibbon, J.J., Kiely, B., Collins, J.K., and Shanahan, F. (2004) Is the mucosal route of administration essential for probiotic function? Subcutaneous administration is associated with attenuation of murine colitis and arthritis. Gut 53, 694-700.

49. Kalliomaki, M., Salminen, S., Poussa, T., Arvilommi, H., and Isolauri, E. (2003) Probiotics and prevention of atopic disease: 4-year follow-up of a randomised placebo-controlled trial. Lancet 361, 1869-1871.

50. Van Loo, J., Clune, Y., Bennett, M., and Collins, J.K. (2005) The SYNCAN project: goals, set-up, first results and settings of the human intervention study. Br. J. Nutr. 93(Suppl 1), S91-98.

51. He, F., Ouwehand, A.C., Isolauri, E., Hosoda, M., Benno, Y., and Salminen, S. (2001) Differences in composition and mucosal adhesion of bifidobacteria isolated from healthy adults and healthy seniors. Curr. Microbiol. 43, 351354.

52. Mack, D.R., Michail, S., Wei, S., McDougall, L., and Hollingsworth, M.A. (1999) Probiotics inhibit enteropathogenic 
E. coli adherence in vitro by inducing intestinal mucin gene expression. Am. J. Physiol. 276, G941-950.

53. Lee, Y.K., Puong, K.Y., Ouwehand, A.C., and Salminen, S. (2003) Displacement of bacterial pathogens from mucus and Caco-2 cell surface by lactobacilli. J. Med. Microbiol. 52, 925-930.

54. Resta-Lenert, S. and Barrett, K.E. (2003) Live probiotics protect intestinal epithelial cells from the effects of infection with enteroinvasive Escherichia coli (EIEC). Gut 52, 988-997.

55. Boudeau, J., Glasser, A.L., Julien, S., Colombel, J.F., and Darfeuille-Michaud, A. (2003) Inhibitory effect of probiotic Escherichia coli strain Nissle 1917 on adhesion to and invasion of intestinal epithelial cells by adherent-invasive E. coli strains isolated from patients with Crohn's disease. Aliment. Pharmacol. Ther. 18, 45-56.

56. Buck, B.L., Altermann, E., Svingerud, T., and Klaenhammer, T.R. (2005) Functional analysis of putative adhesion factors in Lactobacillus acidophilus NCFM. Appl. Environ. Microbiol. 71, 8344-8351. van Pijkeren, J.P., Canchaya, C., Ryan, K.A., Li, Y., Claesson, M.J., Sheil, B., Steidler, L., O'Mahony, L., Fitzgerald, G.F., van Sinderen, D., and O'Toole, P.W. (2006) Comparative and functional analysis of sortase-dependent proteins in the predicted secretome of Lactobacillus salivarius UCC118. Appl. Environ. Microbiol. 72, 4143-4153.

58. Granato, D., Bergonzelli, G.E., Pridmore, R.D., Marvin, L., Rouvet, M., and Corthesy-Theulaz, I.E. (2004) Cell surface-associated elongation factor Tu mediates the attachment of Lactobacillus johnsonii NCC533 (La1) to human intestinal cells and mucins. Infect. Immun. 72, 2160-2169.

59. Bergonzelli, G.E., Granato, D., Pridmore, R.D., Marvin-Guy, L.F., Donnicola, D., and Corthesy-Theulaz, I.E. (2006) GroEL of Lactobacillus johnsonii La1 (NCC 533) is cell surface associated: potential role in interactions with the host and the gastric pathogen Helicobacter pylori. Infect. Immun. 74, 425-434.

60. Roos, S. and Jonsson, H. (2002) A high-molecular-mass cell-surface protein from Lactobacillus reuteri 1063 adheres to mucus components. Microbiology 148, 433-442.

61. Pretzer, G., Snel, J., Molenaar, D., Wiersma, A., Bron, P.A., Lambert, J., de Vos, W.M., van der Meer, R., Smits, M.A., and Kleerebezem, M. (2005) Biodiversity-based identification and functional characterization of the mannosespecific adhesin of Lactobacillus plantarum. J. Bacteriol. 187, 6128-6136.

62. Michail, S. and Abernathy, F. (2003) Lactobacillus plantarum inhibits the intestinal epithelial migration of neutrophils induced by enteropathogenic Escherichia coli. J. Pediatr. Gastroenterol. Nutr. 36, 385-391.

63. Ouwehand, A.C., Isolauri, E., Kirjavainen, P.V., Tolkko, S., and Salminen, S.J. (2000) The mucus binding of Bifidobacterium lactis Bb12 is enhanced in the presence of Lactobacillus GG and Lact. delbrueckii subsp. bulgaricus. Lett. Appl. Microbiol. 30, 10-13.

64. Freitas, M., Tavan, E., Cayuela, C., Diop, L., Sapin, C., and Trugnan, G. (2003) Host-pathogens cross-talk. Indigenous bacteria and probiotics also play the game. Biol. Cell 95, 503-506.

65. Bron, P.A., Marco, M., Hoffer, S.M., Van Mullekom, E., de Vos, W.M., and Kleerebezem, M. (2004) Genetic characterization of the bile salt response in Lactobacillus plantarum and analysis of responsive promoters in vitro and in situ in the gastrointestinal tract. J. Bacteriol. 186, 7829-7835.

66. Walter, J., Heng, N.C., Hammes, W.P., Loach, D.M., Tannock, G.W., and Hertel, C. (2003) Identification of Lactobacillus reuteri genes specifically induced in the mouse gastrointestinal tract. Appl. Environ. Microbiol. 69, 2044-2051.

67. Penner, R., Fedorak, R.N., and Madsen, K.L. (2005) Probiotics and nutraceuticals: non-medicinal treatments of gastrointestinal diseases. Curr. Opin. Pharmacol. 5, 596-603.

68. Kuhbacher, T., Ott, S.J., Helwig, U., Mimura, T., Rizzello, F., Kleessen, B., Gionchetti, P., Blaut, M., Campieri, M., Folsch, U.R., Kamm, M.A., and Schreiber, S. (2006) Bacterial and fungal microbiota in relation to probiotic therapy (VSL\#3) in pouchitis. Gut 55, 833-841.

69. Yamano, T., Iino, H., Takada, M., Blum, S., Rochat, F., and Fukushima, Y. (2006) Improvement of the human intestinal flora by ingestion of the probiotic strain Lactobacillus johnsonii La1. Br. J. Nutr. 95, 303-312.

70. Irvine, E.J. and Marshall, J.K. (2000) Increased intestinal permeability precedes the onset of Crohn's disease in a subject with familial risk. Gastroenterology 119, 1740-1744.

71. Hooper, L.V. and Gordon, J.I. (2001) Commensal host-bacterial relationships in the gut. Science 292, 1115-1118.

72. Cario, E., Gerken, G., and Podolsky, D.K. (2004) Toll-like receptor 2 enhances ZO-1-associated intestinal epithelial barrier integrity via protein kinase C. Gastroenterology 127, 224-238.

73. Montalto, M., Maggiano, N., Ricci, R., Curigliano, V., Santoro, L., Di Nicuolo, F., Vecchio, F.M., Gasbarrini, A., and Gasbarrini, G. (2004) Lactobacillus acidophilus protects tight junctions from aspirin damage in HT-29 cells. Digestion 69, 225-228.

74. Resta-Lenert, S. and Barrett, K.E. (2006) Probiotics and commensals reverse TNF-alpha- and IFN-gamma-induced dysfunction in human intestinal epithelial cells. Gastroenterology 130, 731-746.

75. Rosenfeldt, V., Benfeldt, E., Valerius, N.H., Paerregaard, A., and Michaelsen, K.F. (2004) Effect of probiotics on gastrointestinal symptoms and small intestinal permeability in children with atopic dermatitis. J. Pediatr. 145, 612616.

Petrof, E.O., Kojima, K., Ropeleski, M.J., Musch, M.W., Tao, Y., De Simone, C., and Chang, E.B. (2004) Probiotics inhibit nuclear factor-kappaB and induce heat shock proteins in colonic epithelial cells through proteasome inhibition. Gastroenterology 127, 1474-1487. (2006) Soluble factors from Lactobacillus GG activate MAPKs and induce cytoprotective heat shock proteins in 
intestinal epithelial cells. Am. J. Physiol. Cell. Physiol. 290, C1018-1030.

78. Banasaz, M., Norin, E., Holma, R., and Midtvedt, T. (2002) Increased enterocyte production in gnotobiotic rats mono-associated with Lactobacillus rhamnosus GG. Appl. Environ. Microbiol. 68, 3031-3034.

79. Yan, F. and Polk, D.B. (2002) Probiotic bacterium prevents cytokine-induced apoptosis in intestinal epithelial cells. J. Biol. Chem. 277, 50959-50965.

80. $\quad$ Neish, A.S., Gewirtz, A.T., Zeng, H., Young, A.N., Hobert, M.E., Karmali, V., Rao, A.S., and Madara, J.L. (2000) Prokaryotic regulation of epithelial responses by inhibition of IkappaB-alpha ubiquitination. Science 289, 1560-1563.

81. Kelly, D., Campbell, J.I., King, T.P., Grant, G., Jansson, E.A., Coutts, A.G., Pettersson, S., and Conway, S. (2004) Commensal anaerobic gut bacteria attenuate inflammation by regulating nuclear-cytoplasmic shuttling of PPARgamma and RelA. Nat. Immunol. 5, 104-112.

82. Jung, H.C., Eckmann, L., Yang, S.K., Panja, A., Fierer, J., Morzycka-Wroblewska, E., and Kagnoff, M.F. (1995) A distinct array of proinflammatory cytokines is expressed in human colon epithelial cells in response to bacterial invasion. J. Clin. Invest. 95, 55-65.

83. Bai, A.P., Ouyang, Q., Xiao, X.R., and Li, S.F. (2006) Probiotics modulate inflammatory cytokine secretion from inflamed mucosa in active ulcerative colitis. Int. J. Clin. Pract. 60, 284-288.

84. Borruel, N., Carol, M., Casellas, F., Antolin, M., de Lara, F., Espin, E., Naval, J., Guarner, F., and Malagelada, J.R. (2002) Increased mucosal tumour necrosis factor alpha production in Crohn's disease can be downregulated ex vivo by probiotic bacteria. Gut 51, 659-664.

85. Ewaschuk, J.B., Walker, J.W., Diaz, H., and Madsen, K.L. (2006) Bioproduction of conjugated linoleic acid by probiotic bacteria occurs in vitro and in vivo in mice. J. Nutr. 136, 1483-1487.

86. Wehkamp, J., Harder, J., Wehkamp, K., Wehkamp-von Meissner, B., Schlee, M., Enders, C., Sonnenborn, U., Nuding, S., Bengmark, S., Fellermann, K., Schroder, J.M., and Stange, E.F. (2004) NF-kappaB- and AP-1-mediated induction of human beta defensin-2 in intestinal epithelial cells by Escherichia coli Nissle 1917: a novel effect of a probiotic bacterium. Infect. Immun. 72, 5750-5758.

87. Rakoff-Nahoum, S., Paglino, J., Eslami-Varzaneh, F., Edberg, S., and Medzhitov, R. (2004) Recognition of commensal microflora by toll-like receptors is required for intestinal homeostasis. Cell 118, 229-241.

88. $\quad$ Fukata, M., Michelsen, K.S., Eri, R., Thomas, L.S., Hu, B., Lukasek, K., Nast, C.C., Lechago, J., Xu, R., Naiki, Y., Soliman, A., Arditi, M., and Abreu, M.T. (2005) Toll-like receptor-4 is required for intestinal response to epithelial injury and limiting bacterial translocation in a murine model of acute colitis. Am. J. Physiol. Gastrointest. Liver Physiol. 288, G1055-1065.

89. McCarthy, J., O'Mahony, L., O'Callaghan, L., Sheil, B., Vaughan, E.E., Fitzsimons, N., Fitzgibbon, J., O'Sullivan, G.C., Kiely, B., Collins, J.K., and Shanahan, F. (2003) Double blind, placebo controlled trial of two probiotic strains in interleukin 10 knockout mice and mechanistic link with cytokine balance. Gut 52, 975-980.

90. Cross, M.L. (2002) Microbes versus microbes: immune signals generated by probiotic lactobacilli and their role in protection against microbial pathogens. FEMS Immunol. Med. Microbiol. 34, 245-253.

91. Christensen, H.R., Frokiaer, H., and Pestka, J.J. (2002) Lactobacilli differentially modulate expression of cytokines and maturation surface markers in murine dendritic cells. J. Immunol. 168, 171-178.

92. Hart, A.L., Lammers, K., Brigidi, P., Vitali, B., Rizzello, F., Gionchetti, P., Campieri, M., Kamm, M.A., Knight, S.C., and Stagg, A.J. (2004) Modulation of human dendritic cell phenotype and function by probiotic bacteria. Gut 53, 1602-1609.

93. O'Mahony, L., O'Callaghan, L., McCarthy, J., Shilling, D., Scully, P., Sibartie, S., Kavanagh, E., Kirwan, W.O., Redmond, H.P., Collins, J.K., and Shanahan, F. (2006) Differential cytokine response from dendritic cells to commensal and pathogenic bacteria in different lymphoid compartments in humans. Am. J. Physiol. Gastrointest. Liver Physiol. 290, G839-845.

94. Smits, H.H., Engering, A., van der Kleij, D., de Jong, E.C., Schipper, K., van Capel, T.M., Zaat, B.A., Yazdanbakhsh, M., Wierenga, E.A., van Kooyk, Y., and Kapsenberg, M.L. (2005) Selective probiotic bacteria induce IL-10producing regulatory $\mathrm{T}$ cells in vitro by modulating dendritic cell function through dendritic cell-specific intercellular adhesion molecule 3-grabbing nonintegrin. J. Allergy Clin. Immunol. 115, 1260-1267.

95. Schultz, M., Veltkamp, C., Dieleman, L.A., Grenther, W.B., Wyrick, P.B., Tonkonogy, S.L., and Sartor, R.B. (2002) Lactobacillus plantarum $299 \mathrm{~V}$ in the treatment and prevention of spontaneous colitis in interleukin-10-deficient mice. Inflamm. Bowel Dis. 8, 71-80.

96. Sheil, B., MacSharry, J., O'Callaghan, L., O'Riordan, A., Waters, A., Morgan, J., Collins, J.K., O'Mahony, L., and Shanahan, F. (2006) Role of interleukin (IL-10) in probiotic-mediated immune modulation: an assessment in wildtype and IL-10 knock-out mice. Clin. Exp. Immunol. 144, 273-280.

97. Madsen, K., Cornish, A., Soper, P., McKaigney, C., Jijon, H., Yachimec, C., Doyle, J., Jewell, L., and De Simone, C. (2001) Probiotic bacteria enhance murine and human intestinal epithelial barrier function. Gastroenterology 121, 580-591.

98. Mohamadzadeh, M., Olson, S., Kalina, W.V., Ruthel, G., Demmin, G.L., Warfield, K.L., Bavari, S., and Klaenhammer, T.R. (2005) Lactobacilli activate human dendritic cells that skew $\mathrm{T}$ cells toward T helper 1 polarization. Proc. Natl. Acad. Sci. U. S. A. 102, 2880-2885.

99. Di Giacinto, C., Marinaro, M., Sanchez, M., Strober, W., and Boirivant, M. (2005) Probiotics ameliorate recurrent Th1-mediated murine colitis by inducing IL-10 and IL-10-dependent TGF-beta-bearing regulatory cells. J. Immunol. 
174, 3237-3246.

100. Fujii, T., Ohtsuka, Y., Lee, T., Kudo, T., Shoji, H., Sato, H., Nagata, S., Shimizu, T., and Yamashiro, Y. (2006) Bifidobacterium breve enhances transforming growth factor beta1 signaling by regulating Smad7 expression in preterm infants. J. Pediatr. Gastroenterol. Nutr. 43, 83-88.

101. Braat, H., van den Brande, J., van Tol, E., Hommes, D., Peppelenbosch, M., and van Deventer, S. (2004) Lactobacillus rhamnosus induces peripheral hyporesponsiveness in stimulated CD4+ $\mathrm{T}$ cells via modulation of dendritic cell function. Am. J. Clin. Nutr. 80, 1618-1625.

102. Sudo, N., Sawamura, S., Tanaka, K., Aiba, Y., Kubo, C., and Koga, Y. (1997) The requirement of intestinal bacterial flora for the development of an IgE production system fully susceptible to oral tolerance induction. J. Immunol. 159, 1739-1745.

103. Rautava, S., Kalliomaki, M., and Isolauri, E. (2002) Probiotics during pregnancy and breast-feeding might confer immunomodulatory protection against atopic disease in the infant. J. Allergy Clin. Immunol. 109, 119-121.

104. Sturm, A., Rilling, K., Baumgart, D.C., Gargas, K., Abou-Ghazale, T., Raupach, B., Eckert, J., Schumann, R.R., Enders, C., Sonnenborn, U., Wiedenmann, B., and Dignass, A.U. (2005) Escherichia coli Nissle 1917 distinctively modulates T-cell cycling and expansion via toll-like receptor 2 signaling. Infect. Immun. 73, 1452-1465.

105. Di Marzio, L., Russo, F.P., D'Alo, S., Biordi, L., Ulisse, S., Amicosante, G., De Simone, C., and Cifone, M.G. (2001) Apoptotic effects of selected strains of lactic acid bacteria on a human $\mathrm{T}$ leukemia cell line are associated with bacterial arginine deiminase and/or sphingomyelinase activities. Nutr. Cancer 40, 185-196.

106. Rodrigues, A.C., Cara, D.C., Fretez, S.H., Cunha, F.Q., Vieira, E.C., Nicoli, J.R., and Vieira, L.Q. (2000) Saccharomyces boulardii stimulates sIgA production and the phagocytic system of gnotobiotic mice. J. Appl. Microbiol. 89, 404-414.

107. Olivares, M., Diaz-Ropero, M.P., Gomez, N., Lara-Villoslada, F., Sierra, S., Maldonado, J.A., Martin, R., Rodriguez, J.M., and Xaus, J. (2006) The consumption of two new probiotic strains, Lactobacillus gasseri CECT 5714 and Lactobacillus coryniformis CECT 5711, boosts the immune system of healthy humans. Int. Microbiol. 9, 47-52.

108. Fang, H., Elina, T., Heikki, A., and Seppo, S. (2000) Modulation of humoral immune response through probiotic intake. FEMS Immunol. Med. Microbiol. 29, 47-52.

109. Sheih, Y.H., Chiang, B.L., Wang, L.H., Liao, C.K., and Gill, H.S. (2001) Systemic immunity-enhancing effects in healthy subjects following dietary consumption of the lactic acid bacterium Lactobacillus rhamnosus HN001. J. Am. Coll. Nutr. 20, 149-156.

110. Rautava, S., Arvilommi, H., and Isolauri, E. (2006) Specific probiotics in enhancing maturation of IgA responses in formula-fed infants. Pediatr. Res. 60, 221-224.

111. Fantini, M.C., Becker, C., Monteleone, G., Pallone, F., Galle, P.R., and Neurath, M.F. (2004) Cutting edge: TGF-beta induces a regulatory phenotype in CD4+CD25- T cells through Foxp3 induction and down-regulation of Smad7. $J$. Immunol. 172, 5149-5153.

112. Maassen, C.B., van Holten-Neelen, C., Balk, F., den Bak-Glashouwer, M.J., Leer, R.J., Laman, J.D., Boersma, W.J., and Claassen, E. (2000) Strain-dependent induction of cytokine profiles in the gut by orally administered Lactobacillus strains. Vaccine 18, 2613-2623.

113. Rachmilewitz, D., Katakura, K., Karmeli, F., Hayashi, T., Reinus, C., Rudensky, B., Akira, S., Takeda, K., Lee, J., Takabayashi, K., and Raz, E. (2004) Toll-like receptor 9 signaling mediates the anti-inflammatory effects of probiotics in murine experimental colitis. Gastroenterology 126, 520-528.

114. Rachmilewitz, D., Karmeli, F., Shteingart, S., Lee, J., Takabayashi, K., and Raz, E. (2006) Immunostimulatory oligonucleotides inhibit colonic proinflammatory cytokine production in ulcerative colitis. Inflamm. Bowel Dis. 12, 339-345.

115. Rachmilewitz, D., Karmeli, F., Takabayashi, K., Hayashi, T., Leider-Trejo, L., Lee, J., Leoni, L.M., and Raz, E. (2002) Immunostimulatory DNA ameliorates experimental and spontaneous murine colitis. Gastroenterology 122, 1428-1441.

116. Jijon, H., Backer, J., Diaz, H., Yeung, H., Thiel, D., McKaigney, C., De Simone, C., and Madsen, K. (2004) DNA from probiotic bacteria modulates murine and human epithelial and immune function. Gastroenterology 126, 13581373.

117. Hoarau, C., Lagaraine, C., Martin, L., Velge-Roussel, F., and Lebranchu, Y. (2006) Supernatant of Bifidobacterium breve induces dendritic cell maturation, activation, and survival through a Toll-like receptor 2 pathway. J. Allergy Clin. Immunol. 117, 696-702.

118. Menard, S., Candalh, C., Bambou, J.C., Terpend, K., Cerf-Bensussan, N., and Heyman, M. (2004) Lactic acid bacteria secrete metabolites retaining anti-inflammatory properties after intestinal transport. Gut 53, 821-828.

119. Grangette, C., Nutten, S., Palumbo, E., Morath, S., Hermann, C., Dewulf, J., Pot, B., Hartung, T., Hols, P., and Mercenier, A. (2005) Enhanced antiinflammatory capacity of a Lactobacillus plantarum mutant synthesizing modified teichoic acids. Proc. Natl. Acad. Sci. U. S. A. 102, 10321-10326.

120. Sengul, N., Aslim, B., Ucar, G., Yucel, N., Isik, S., Bozkurt, H., Sakaogullari, Z., and Atalay, F. (2006) Effects of exopolysaccharide-producing probiotic strains on experimental colitis in rats. Dis. Colon Rectum 49, 250-258.

121. Coakley, M., Ross, R.P., Nordgren, M., Fitzgerald, G., Devery, R., and Stanton, C. (2003) Conjugated linoleic acid biosynthesis by human-derived Bifidobacterium species. J. Appl. Microbiol. 94, 138-145.

122. Steidler, L., Hans, W., Schotte, L., Neirynck, S., Obermeier, F., Falk, W., Fiers, W., and Remaut, E. (2000) Treatment 
of murine colitis by Lactococcus lactis secreting interleukin-10. Science 289, 1352-1355.

123. Vandenbroucke, K., Hans, W., Van Huysse, J., Neirynck, S., Demetter, P., Remaut, E., Rottiers, P., and Steidler, L. (2004) Active delivery of trefoil factors by genetically modified Lactococcus lactis prevents and heals acute colitis in mice. Gastroenterology 127, 502-513.

124. Steidler, L. (2001) Lactococcus lactis, a tool for the delivery of therapeutic proteins treatment of IBD. TheScientificWorldJOURNAL 1, 216-217.

125. Braat, H., Rottiers, P., Hommes, D.W., Huyghebaert, N., Remaut, E., Remon, J.P., van Deventer, S.J., Neirynck, S., Peppelenbosch, M.P., and Steidler, L. (2006) A phase I trial with transgenic bacteria expressing interleukin-10 in Crohn's disease. Clin. Gastroenterol. Hepatol. 4, 754-759.

126. Paton, A.W., Morona, R., and Paton, J.C. (2006) Designer probiotics for prevention of enteric infections. Nat. Rev. Microbiol. 4, 193-200.

127. Focareta, A., Paton, J.C., Morona, R., Cook, J., and Paton, A.W. (2006) A recombinant probiotic for treatment and prevention of cholera. Gastroenterology 130, 1688-1695.

128. Claesson, M.J., Li, Y., Leahy, S., Canchaya, C., van Pijkeren, J.P., Cerdeno-Tarraga, A.M., Parkhill, J., Flynn, S., O'Sullivan, G.C., Collins, J.K., Higgins, D., Shanahan, F., Fitzgerald, G.F., van Sinderen, D., and O'Toole, P.W. (2006) Multireplicon genome architecture of Lactobacillus salivarius. Proc. Natl. Acad. Sci. U. S. A. 103, 6718-6723.

129. Qin, H.L., Shen, T.Y., Gao, Z.G., Fan, X.B., Hang, X.M., Jiang, Y.Q., and Zhang, H.Z. (2005) Effect of lactobacillus on the gut microflora and barrier function of the rats with abdominal infection. World J. Gastroenterol. 11, 25912596.

130. Lievin-Le Moal, V., Amsellem, R., Servin, A.L., and Coconnier, M.H. (2002) Lactobacillus acidophilus (strain LB) from the resident adult human gastrointestinal microflora exerts activity against brush border damage promoted by a diarrhoeagenic Escherichia coli in human enterocyte-like cells. Gut 50, 803-811.

131. Zareie, M., Johnson-Henry, K., Jury, J., Yang, P.C., Ngan, B.Y., McKay, D.M., Soderholm, J.D., Perdue, M.H., and Sherman, P.M. (2006) Probiotics prevent bacterial translocation and improve intestinal barrier function in rats following chronic psychological stress. Gut 55, 1553-1560.

132. Garcia-Lafuente, A., Antolin, M., Guarner, F., Crespo, E., and Malagelada, J.R. (2001) Modulation of colonic barrier function by the composition of the commensal flora in the rat. Gut 48, 503-507.

133. Mattar, A.F., Teitelbaum, D.H., Drongowski, R.A., Yongyi, F., Harmon, C.M., and Coran, A.G. (2002) Probiotics upregulate MUC-2 mucin gene expression in a Caco-2 cell-culture model. Pediatr. Surg. Int. 18, 586-590.

134. Mack, D.R., Ahrne, S., Hyde, L., Wei, S., and Hollingsworth, M.A. (2003) Extracellular MUC3 mucin secretion follows adherence of Lactobacillus strains to intestinal epithelial cells in vitro. Gut 52, 827-833.

\section{This article should be cited as follows:}

O’Hara, A.M. and Shanahan, F. (2007) Mechanisms of action of probiotics in intestinal diseases. TheScientificWorldJOURNAL 7, 31-46. DOI 10.1100/tsw.2007.26. 


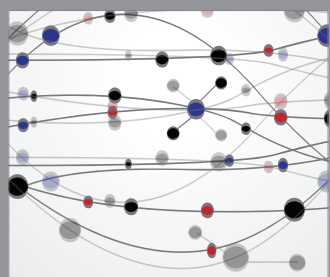

The Scientific World Journal
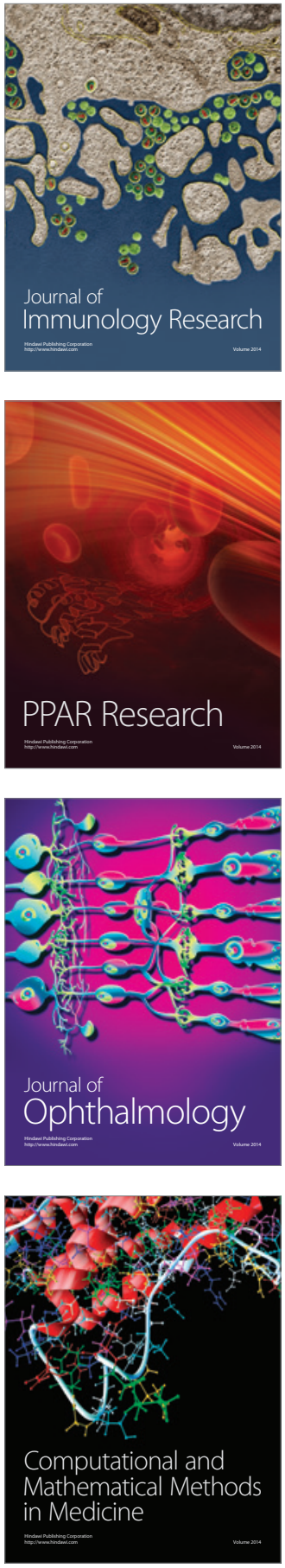

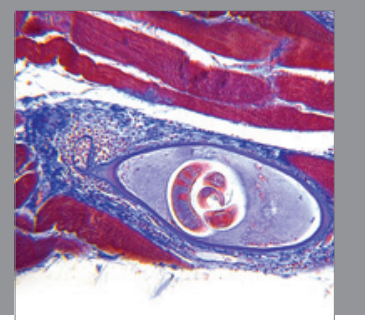

Gastroenterology

Research and Practice
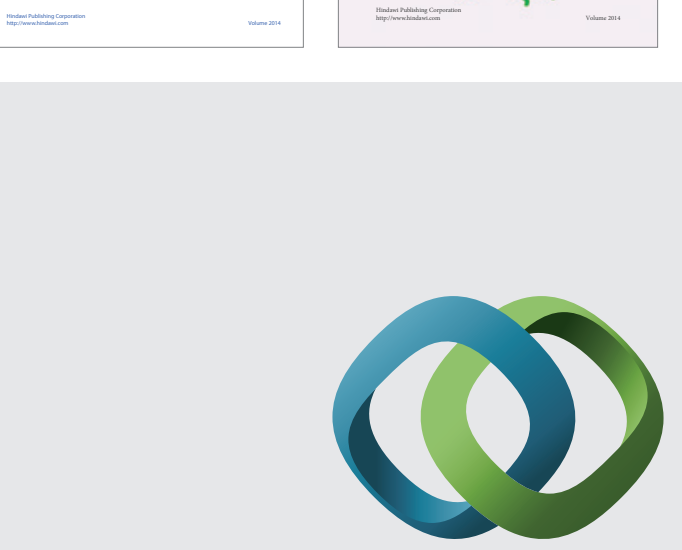

\section{Hindawi}

Submit your manuscripts at

http://www.hindawi.com
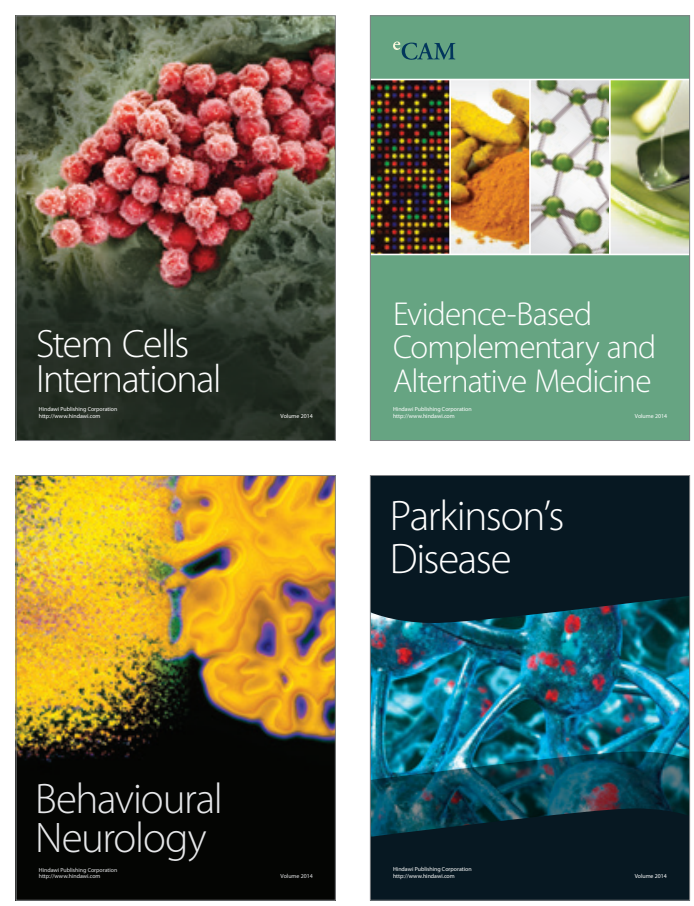

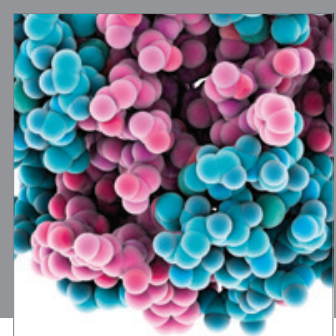

Journal of
Diabetes Research

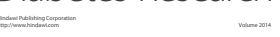

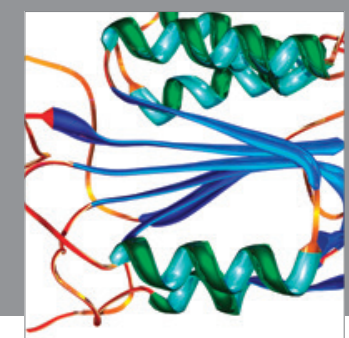

Disease Markers
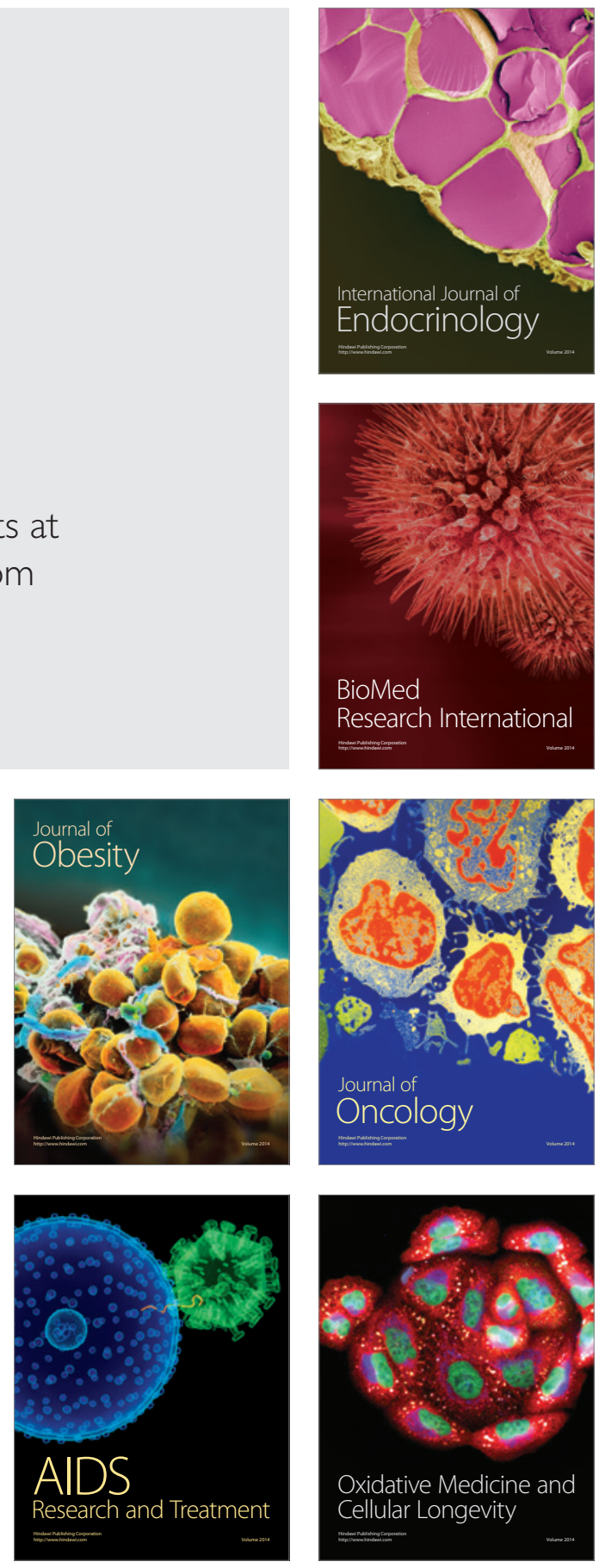